\title{
Effects of constant rate infusion of anesthetic or analgesic drugs on general anesthesia with isoflurane: A retrospective study in 200 dogs
}

\author{
Efeitos da infusão intravenosa contínua de fármacos anestésicos \\ ou analgésicos sobre a anestesia geral com isoflurano: Estudo \\ retrospectivo em 200 cães
}

\author{
Sofia de Amorim Cerejo ${ }^{1}$; Ewaldo de Mattos Júnior ${ }^{2}$; Lilian Toshiko Nishimura ${ }^{1}$; \\ Carolina Quarterone ${ }^{3}$; Leandro Guimarães Franco ${ }^{4 *}$
}

\begin{abstract}
Constant rate infusion (CRI) shows several advantages in balanced anesthesia, such as reduction of requirement for inhaled anesthetics and control of pain. The most commonly used drugs in these protocols are local anesthetics, dissociative, and opioids, which may be administered alone or in combinations. We evaluated the records of 200 dogs that underwent various surgical procedures with anesthetic or analgesic CRI in the perioperative period during 2011 and 2012 at the Veterinary Hospital of Franca University (Unifran), and identified possible complications during the transoperative period. Records evaluated included clinical state, laboratory tests, drugs used in premedication and induction, and CRI protocol. Acepromazine and morphine were the main drugs used in premedication. Propofol was used to induce anesthesia alone or in combination with other agents. We evaluated records of the 25 different CRI protocols. Fentanyl was the main drug employed in CRI, either alone or in combination. There were 128 episodes of anesthetic complications during CRI;the most common were hypotension, hypertension, and tachycardia, which occurred in 43 (32\%), 35 (26.3\%), and 19 (14.2\%) dogs, respectively. Cardiac arrhythmia was reported in only 4 dogs. Signs of respiratory depression were present in dogs treated with 6 different CRI protocols. The consumption of isoflurane (vol \%) reduced between $15.7 \%$ and $21.05 \%$ after 30 minutes of the CRI in the fentanyl and fentanyl-lidocaine-ketamine CRI groups $(p<0.05)$. In conclusion, CRI is a valid component of balanced anesthesia in dogs, safe, and has a low incidence of adverse effects. However, future studies are warranted to describe the results of the clinical use of CRI to better characterize and refine this technique.
\end{abstract}

Key words: Continuous intravenous infusion, fentanyl, ketamine, lidocaine, morphine

\section{Resumo}

O uso de técnicas de infusão contínua (IC) possui inúmeras vantagens na anestesia balanceada, como a redução do requerimento de anestésicos inalatórios e controle da dor. Os fármacos mais comumente utilizados nestes protocolos são os anestésicos locais, dissociativos e opioides, que podem ser administrados isoladamente ou em associações. Foram avaliados os prontuários de 200 cães que foram submetidos a diversos procedimentos cirúrgicos com IC de anestésicos ou analgésicos no período perioperatório durante 2011 e 2012 no Hospital Veterinário da Universidade de Franca (Unifran).

Pós-graduandas, Universidade de Franca, UNIFRAN, Franca, SP. E-mail: socerejo@uol.com.br; liliannishimura@hotmail.com

2 Prof. Adjunto, UNIFRAN, Franca, SP, Brasil. E-mail: ewaldomattos@hotmail.com

3 Pós-graduanda, Universidade Estadual Paulista "Júlio de Mesquita Filho", Campus Botucatu, UNESP, Botucatu, SP. E-mail: cquarterone@hotmail.com

4 Prof. Adjunto, Universidade Estadual de Santa Cruz, UESC, Ilhéus, BA. Orientador. E-mail: lg.franco@yahoo.com.br

* Author for correspondence 
Foram identificadas possíveis complicações durante o período trans-operatório. Os registros avaliados incluíram estado clínico, exames laboratoriais, fármacos utilizados na pré-medicação e indução, e protocolos de IC. Acepromazina e morfina foram os principais fármacos usados na pré-medicação. $\mathrm{O}$ propofol foi utilizado para induzir a anestesia, isolado ou em associação com outros agentes. Foram avaliados os registros de 25 protocolos diferentes de IC. O fentanil foi o principal fármaco utilizado na IC, isoladamente ou em associação. Houve 128 episódios de complicações anestésicas durante a IC; os mais comuns foram hipotensão, hipertensão e taquicardia, que ocorreram em 43 (32\%), 35 (26,3\%), e $19(14,2 \%)$ cães, respectivamente. Arritmia cardíaca foi relatada em apenas 4 cães. Sinais de depressão respiratória estiveram presentes em cães tratados com 6 diferentes protocolos de IC, especialmente com fentanil. O consumo de isoflurano (vol.\%) reduziu entre $15,7 \%$ e $21,05 \%$, após 30 minutos da IC nos grupos fentanil e fentanil-lidocaína-cetamina $(\mathrm{p}<0,05)$. Em conclusão, a IC é um componente válido da anestesia balanceada em cães, segura e tem baixa incidência de efeitos adversos. No entanto, estudos futuros são necessários para descrever os resultados do uso clínico da IC para melhor caracterizar e aperfeiçoar esta técnica.

Palavras-chave: Cetamina, fentanil, infusão intravenosa contínua, lidocaína, morfina

\section{Introduction}

In the veterinary field, prevention and treatment of pain has been neglected for many years. However, recently, the value of prevention and treatment of pain in animals has been recognized (JONES, 2008), and there has been considerable progress in development of safer anesthetic agents, knowledge of the pathophysiology and treatment of pain, and understanding of the importance of perioperative care (KEHLET; DAHL, 2003).

Pain management includes analgesic techniques before, during, and after surgery to decrease somatic and autonomic reflex responses to nociceptive stimuli, reduce stress and anxiety, and ensure comfort and well-being (KEHLET; DAHL, 2003). With these objectives, the adoption of various protocols of multimodal analgesia and balanced anesthesia has been effective in establishing adequate analgesia and, potentially, reducing the adverse effects of each drug (MUIR; WIESE; MARCH, 2003; ORTEGA; CRUZ, 2011; AGUADO; BENITO; SEGURA, 2011).

Multiple techniques can be used to ensure the prevention and treatment of pain, such as subcutaneous, intramuscular, intravenous, or oral administration of opioids and anti-inflammatory agents; regional blockade or blockade of peripheral nerves with local anesthetics; epidural administration of local anesthetics with or without opioids (KEHLET; DAHL, 2003; JONES, 2008; LAMONT, 2008); and administration of analgesics by constant rate infusion (CRI) (MUIR; WIESE.; MARCH, 2003).

With benefits in the perioperative period and for prolonged periods after surgery, CRI administration of analgesics, anesthetics, or both has been increasingly adopted in recent years (WAGNER et al., 2002; MATSUBARA et al., 2009; ORTEGA; CRUZ, 2011). Depending on the procedure and drug combination, perioperative CRI can provide analgesia (LUCAS et al., 2001; WAGNER et al., 2002; BUFALARI et al., 2007; ORTEGA; CRUZ, 2011) and significantly decrease the minimum alveolar concentration (MAC) of inhaled anesthetics (MUIR; WIESE; MARCH, 2003; MATSUBARA et al., 2009; UEYAMA et al., 2009; AGUADO; BENITO; SEGURA, 2011), with minimal adverse effects.

However, it should be noted that these infusions are not without risks to the patient (CORLETTO, 2007). Previous studies have reported adverse effects such as disorientation, salivation, hyperactivity, and apneustic respiration with ketamine CRI (BERGADANO et al., 2009); dose-dependent sedation and hypothermia with morphine CRI in conscious dogs (GUEDES et al., 2007); respiratory depression with fentanyl CRI (BUFALARI et al., 2007); histamine release with 
morphine CRI (GUEDES; RUDÉ; RIDER, 2006); decreased urinary output in healthy and traumatized dogs with morphine or fentanyl CRI (ANDERSON; DAY, 2008); and ataxia and vomiting with highdose lidocaine CRI (MATSUBARA et al., 2009).

The drugs most commonly administered by CRI are ketamine (SOLANO et al., 2006), lidocaine (ORTEGA; CRUZ, 2011), and opioid analgesics such as morphine (LUCAS et al., 2001) and fentanyl (UEYAMA et al., 2009). Ketamine is a noncompetitive antagonist of the $\mathrm{N}$-methyl D-aspartate (NMDA) receptor and potentially has significant anti-hyperalgesic effects when administered by CRI. The analgesic effects of ketamine are inconsistent and appear related to infusion rate (BOSCAN et al., 2005; BERGADANO et al., 2009). The use of ketamine at a rate of $10 \mu \mathrm{g}$ $\mathrm{kg}^{-1} \mathrm{~min}^{-1}$ in combination with fentanyl was reported to promote postoperative comfort in patients undergoing amputation of the forelimb (WAGNER et al., 2002). Regarding the reduction of MAC, CRI rates that yielded plasma concentrations of 0.5 , 1 , and $2 \mu \mathrm{g} \mathrm{ml}^{-1}$ were shown to reduce isoflurane MAC by up to $84 \%$, with minimal adverse effects (SOLANO et al., 2006).

The use of lidocaine in CRI during anesthesia in dogs has been intensively discussed in recent years (MATSUBARA et al., 2009; ORTEGA; CRUZ, 2011). Lidocaine CRI was reported to reduce isoflurane MAC by $18.7 \%$ at a dose of $50 \mu \mathrm{g} \mathrm{kg}^{-1} \mathrm{~min}^{-1}$ and $43.3 \%$ at $200 \mu \mathrm{g} \mathrm{kg}^{-1} \mathrm{~min}^{-1}$, without adverse cardiovascular effects in healthy dogs (VALVERDE et al., 2004), and to reduce sevoflurane MAC by $15 \%$ at $50 \mu \mathrm{g} \mathrm{kg}^{-1} \mathrm{~min}^{-1}$ and $37 \%$ at $200 \mu \mathrm{g} \mathrm{kg}^{-1} \mathrm{~min}^{-1}$ (MATSUBARA et al., 2009). Lidocaine also has analgesic effects when used in CRI at a dose of $50 \mu \mathrm{g} \mathrm{kg}^{-1} \mathrm{~min}^{-1}$ and helps prevent sympathetic response to surgical stimulation, reducing the intraoperative use of opioids without causing significant hemodynamic instability (ORTEGA; CRUZ, 2011).

The mechanism of action of lidocaine in reduction of MAC is not completely understood, but believed to be related to the analgesic effects of the drug administered intravenously or depression of the central nervous system caused by blocking cells in the spinal cord, neurons in the dorsal horn, and neurons responsible for transmission of visceral pain (SMITH et al., 2004).

Use of opioids in CRI techniques has focused on morphine and fentanyl. The use of morphine in CRI has been associated with good analgesia (LAMONT; MATHEWS, 2007) and significant reduction in MAC in dogs (MUIR; WIESE.; MARCH, 2003; AGUADO; BENITO; SEGURA, 2011). The analgesic effects observed at a dose of $0.12 \mathrm{mg} \mathrm{kg}^{-1} \mathrm{~h}^{-1}$ were similar to the effects of intramuscular administration at a dose of $1 \mathrm{mg} \mathrm{kg}^{-1}$, with minor adverse effects (LUCAS et al., 2001), and significant antinociception was maintained at a dose of $0.15 \pm 0.02 \mathrm{mg} \mathrm{kg}^{-1} \mathrm{~h}^{-1}$ in dogs undergoing von Frey testing (KUKANICH; LASCELLES; PAPICH, 2005). With respect to MAC, reduction of isoflurane MAC by $48 \%$ was observed with a dose of $3.3 \mu \mathrm{g} \mathrm{kg}^{-1} \mathrm{~min}^{-1}$ (MUIR; WIESE; MARCH, 2003).

Fentanyl, having a rapid onset of action and short duration, is useful for CRI in balanced anesthesia, and decreases isoflurane MAC in dogs by $35 \%$ at a dose of $0.15 \mu \mathrm{g} \mathrm{kg}^{-1} \mathrm{~min}^{-1}$ without cardiac adverse effects (UEYAMA et al., 2009) while providing adequate analgesia during the perioperative period (BUFALARI et al., 2007).

In addition, the use of drug combinations in CRI techniques can enable reduction of the original doses while preserving the desirable effects in analgesia and MAC reduction of inhaled anesthetics, with minimal adverse effects (MUIR; WIESE; MARCH, 2003). Accordingly, studies have shown a reduction of isoflurane MAC by $45 \%$ with infusion of morphine, lidocaine, and ketamine (MUIR; WIESE; MARCH, 2003) and by $97 \%$ with infusion of fentanyl, lidocaine, and ketamine (AGUADO; BENITO; SEGURA, 2011). Studies have also shown the effects of CRI on the requirement of 
sevoflurane, with a $62.8 \%$ reduction in MAC with a combination of ketamine and lidocaine (WILSON et al., 2008).

Despite several studies demonstrating the effectiveness and relative safety of different protocols of CRI in dogs, information on clinical trials is scarce. Few studies have demonstrated the clinical use of CRI in procedures involving surgical stimulation, and no retrospective studies or metaanalyses were found in the literature. Thus, the present study aimed to conduct a retrospective study of 200 dogs that underwent various CRI protocols together with inhalation anesthesia with isoflurane for surgical procedures, and identify possible cardiovascular abnormalities and complications during the transoperative period.

\section{Material and Methods}

The complete anesthetic records of 200 dogs that underwent various surgical procedures with anesthetic or analgesic continuous intravenous infusion during the perioperative period at the Veterinary Hospital of University of Franca (Unifran) during2011 and 2012 were reviewed. This retrospective study was performed after prior approval by the Animal Ethics Committee of the University of Franca (protocol 038/12).

Records included body weight, sex, age, and physical status according to the American Society of Anesthesiology (ASA). We also evaluated the results of standard laboratory tests including packed cell volume, total solids, urea, creatinine, alanine aminotransferase, alkaline phosphatase, and albumin (Table 1).

The anesthetic technique, including all drugs administered in the perioperative period, was recorded. Data were collected pertaining to premedication and induction agents for each case. The routine premedication and induction agents are presented in Table 2 and Table 3.

Regardless of surgical procedure, anesthesia induction was followed by endotracheal intubation and general anesthesiawasmaintainedwith isoflurane vaporized in $100 \%$ oxygen and delivered via an appropriate breathing system (Bain or circle circuit). All patients were allowed to breathe spontaneously during anesthesia, unless end-tidal $\mathrm{CO}_{2}$ was higher than $45 \mathrm{mmHg}$, in which case intermittent positive pressure ventilation was imposed to restore and maintain normocapnia. Lactated Ringer's solution was infused intravenously at $5-10 \mathrm{ml} \mathrm{kg}^{-1}$ hour $^{-1}$ during anesthesia in all dogs.

Local or regional anesthetic blocks (e.g., epidural anesthesia, brachial plexus block), when performed, were recorded and presented in the results.

Physiological parameters were monitored and recorded at 5-minutes intervals throughout anesthesia. A multi-parameter monitor was used to obtain heart rate (HR), respiratory rate, electrocardiogram, end-tidal carbon dioxide concentration, arterial hemoglobin oxygen saturation, and arterial blood pressure. Systolic arterial blood pressure (SAP) was measured using an oscillometric technique with a cuff of appropriate size $(30-40 \%$ of the circumference of the arm) placed on the distal third of the left forearm, and the reading was confirmed using a Doppler flow detector (MEDMEGA, Doppler Vascular). The mean arterial blood pressure (MAP) was monitored via a catheter placed in the dorsal pedal artery and connected to an aneroid manometer system.

The CRI was prepared by adding the drugs to the lactated Ringer's solution and were administered considering the fluid rate cited above with a volumetric infusion pump peristaltic roller (SAMTRONIC, ST-550T2). The drugs administered were morphine $\left(1.66 \mu \mathrm{g} \mathrm{kg}^{-1} \mathrm{~min}^{-1}\right)$, fentanyl $\left(2.5-15 \mu \mathrm{g} \mathrm{kg}^{-1}\right.$ hour $\left.{ }^{-1}\right)$, ketamine $(10-20 \mu \mathrm{g}$ $\left.\mathrm{kg}^{-1} \mathrm{~min}^{-1}\right)$, and lidocaine $\left(30-50 \mu \mathrm{g} \mathrm{kg} \mathrm{min}^{-1}\right)$ alone or in combination (Table 4). The CRI was preceded by a bolus of $0.3-0.5 \mathrm{mg} \mathrm{kg}^{-1}$ morphine intramuscularly in the preanesthetic period, $2-5 \mu \mathrm{g} \mathrm{kg}^{-1}$ fentanyl intravenously, $0.5-1.0 \mathrm{mg} \mathrm{kg}^{-1}$ ketamine intravenously, or $1-2 \mathrm{mg} \mathrm{kg}^{-1}$ lidocaine intravenously. 
Anesthetic complications recorded included bradycardia (HR $<60$ bpm), hypotension (MAP $<$ $60 \mathrm{mmHg}$ or $\mathrm{SAP}<90 \mathrm{mmHg}$, cardiovascular response to surgical stimulation $(20 \%$ increase in HR, MAP, or SAP compared with prestimulus value), apnea, cardiac arrhythmia, and mortality (Figure 1).

A complication was considered to have occurred if it was noted at any time point on the anesthetic record, even if transient. The complications were treated if they were prolonged and severe, and the treatment varied according to complication. Bradycardia was treated with atropine; hypotension was treated with dobutamine, phenylephrine or ephedrine; increased HR, or MAP or SAP, due to surgical stimulation was treated by increasing isoflurane concentration; and apnea was remedied by assisted ventilation until the animal was able to ventilate on its own.

Signs of respiratory depression, such as hypercapnia, were also evaluated. This was characterized as an increase in the expired fraction of $\mathrm{CO}_{2}(>50 \mathrm{mmHg})$, necessitating controlled ventilation.

The isoflurane consumption was recorded considering the vaporization observed (volume percent) on a calibrated vaporizer during the transoperative period. For analysis, only protocols with 6 or more repetitions and employing the circle system were considered (Table 6).

The data for the anesthetic protocols were presented in descriptive form with their respective frequencies. Differences in inspiratory concentration of isoflurane (volume percent) were compared by one-way repeated measures ANOVA, followed by Student-Newman-Keuls post hoc test (Sigma Stat, version 11.0).

\section{Results}

There were 200 dogs, 138 female $(69 \%)$ and 62 male (31\%). Our patient population included 70 mongrel dogs (35\%), 22 Poodles (11\%), 20 American pitbull terriers (10\%), 16 Dachshunds (8\%), 14 Boxers (7\%), 9 Rottweilers (4.5\%), 8 Pinschers (4\%), 7 English cocker spaniels (3.5\%), 5 Labrador retrievers (2.5\%), 4 Shihtzus (2\%), 3 Brazilian terriers (1.5\%), 3 Fila brasileiros (1.5\%), and 14 dogs of other breeds (9.5\%). Mean age was $7.4 \pm 3.9$ years and body weight was $17.8 \pm 12.5 \mathrm{~kg}$.

A total of 200 records [3 (1.5\%) in dogs assessed as ASA I, $142(71 \%)$ as ASA II, $50(25 \%)$ as ASA III, and $5(2.5 \%)$ as ASA IV] met the inclusion criteria. Table 7 shows the proportions of patients according to surgical procedure together with respective frequencies. With respect to laboratory variables, the majority of dogs had results within the range considered normal for the species. The main variation was observed in total plasma protein with only $34 \%$ of dogs showing results within physiological values (Table 1).

Anesthetic complications were not observed with the use of anesthetic premedication or induction agents. Ninety-eight percent of the dogs received anesthetic premedication. Acepromazine was the main tranquilizer agent used (22\%) administered alone or combined with other agents. Considering the use of opioids, morphine was administered for premedication in $53.3 \%$ of all dogs followed by methadone (14.5\%) and meperidine (14\%).

Miscellaneous agents used in anesthetic premedication are shown in Table 2.

Propofol was used to induce anesthesia as the sole agent in $50.5 \%$ of the dogs and in combination with other agents in $49.5 \%$ (Table 3 ). 
Table 1. Laboratory results from dogs with respective proportion (\%) with values below, within or above the reference range.

\begin{tabular}{|c|c|c|c|c|}
\hline Parameter & Lower & Normal & Above & $\begin{array}{c}\text { Reference } \\
\text { values* }\end{array}$ \\
\hline $\begin{array}{c}\text { Hematocrit } \\
(\%)\end{array}$ & $38(20.32 \%)$ & $138(73.8 \%)$ & $11(5.88 \%)$ & $37-55$ \\
\hline $\begin{array}{l}\text { Hemoglobin } \\
(\mathrm{g} / \mathrm{dL})\end{array}$ & $30(16.39 \%)$ & $127(69.4 \%)$ & $26(14.21 \%)$ & $12-18$ \\
\hline $\begin{array}{l}\text { Platelets } \\
(\mu 1)\end{array}$ & $31(16.94 \%)$ & $126(68.85 \%)$ & $26(14.21 \%)$ & $180000-400000$ \\
\hline $\begin{array}{c}\text { Leukocytes } \\
(\mu \mathrm{l})\end{array}$ & $3(2.54 \%)$ & $82(69.49 \%)$ & $33(27.97 \%)$ & $6000-18000$ \\
\hline $\begin{array}{l}\text { Alanine Aminotransferase } \\
(\mathrm{U} / \mathrm{L})\end{array}$ & $15(8.47 \%)$ & $139(78.53 \%)$ & $23(12.99 \%)$ & $21-102$ \\
\hline $\begin{array}{l}\text { Alkaline Phosphatase } \\
(\mathrm{U} / \mathrm{L})\end{array}$ & $2(1.17 \%)$ & $128(74.85 \%)$ & $41(23.98 \%)$ & $20-156$ \\
\hline $\begin{array}{c}\text { Urea } \\
(\mathrm{mg} / \mathrm{dL})\end{array}$ & $7(3.98 \%)$ & $155(88.07 \%)$ & $14(7.95 \%)$ & $15-65$ \\
\hline Creatinine (mg/dL) & $5(2.84 \%)$ & $164(93.18 \%)$ & $7(3.98 \%)$ & $0.5-1.5$ \\
\hline $\begin{array}{c}\text { Total Plasma Protein }(\mathrm{g} / \\
\mathrm{dL})\end{array}$ & $2(1.21 \%)$ & $65(39.39 \%)$ & $98(59.39 \%)$ & $5.4-7.1$ \\
\hline Albumin (g/dL) & $32(35.56 \%)$ & $57(63.33 \%)$ & $1(1.11 \%)$ & $2.6-4$ \\
\hline
\end{tabular}

*Values by Thrall et al. 2006.

Source: Elaboration of the authors.

Table 2. Preanesthetic agents, doses intervals and respective use frequency (\%) used in different protocols in 200 dogs.

\begin{tabular}{|c|c|c|c|}
\hline Drug or association & $\begin{array}{c}\text { Dose }\left(\mathrm{mg} / \mathrm{kg}^{-1}\right) \\
(\text { minimum }- \text { maximum) }\end{array}$ & $\begin{array}{c}\text { Cases } \\
\text { (n) }\end{array}$ & $\begin{array}{l}\text { Frequency } \\
(\%)\end{array}$ \\
\hline Morphine & $(0.3-0.5)$ & 59 & 29.5 \\
\hline Morphine+Acepromazine & $(0.3-0.5)+(0.03-0.05)$ & 12 & 6 \\
\hline Morphine + Midazolam & $(0.3-0.5)+(0.3-0.4)$ & 22 & 11 \\
\hline Morphine+Acepromazine+Midazolam & $(0.3-0.5)+(0.3-0.4)+(0.02-0.05)$ & 16 & 8 \\
\hline Morphine+Clorpromazine & $0.3+0.7$ & 5 & 2.5 \\
\hline Morphine+Clorpromazine+Midazolam & $(0.3-0.4)+0.7+0.3$ & 3 & 1.5 \\
\hline Tramadol & $(2.0-3.0)$ & 12 & 6 \\
\hline Tramadol+Midazolam & $3.0+0.3$ & 1 & 0.5 \\
\hline Meperidine & $(3.0-4.0)$ & 19 & 9.5 \\
\hline Meperidine + Acepromazine & $(3.0-4.0)+(0.03-0.05)$ & 9 & 4.5 \\
\hline Meperidine+Midazolam & $3+0.3$ & 1 & 0.5 \\
\hline Meperidine+Acepromazine+Midazolam & $3+0.03+0.3$ & 1 & 0.5 \\
\hline Metadone & $(0.3-0.5)$ & 13 & 6.5 \\
\hline Metadone+Acepromazine & $0.3+(0.03-0.05)$ & 5 & 2.5 \\
\hline Methadone+Midazolam & $(0.3-0.5)+(0.3-0.4)$ & 3 & 1.5 \\
\hline Methadone+Acepromazine+Midazolam & $0.3+(0.02-0.03)+0.3$ & 2 & 1 \\
\hline
\end{tabular}


continuação

\begin{tabular}{cccc} 
Methadone+Prometazine & $0.3+(0.4-0.5)$ & 7 \\
Ketamine+Midazolam+Morphine & $(5.0-7.0)+(0.3-0.5)+(0.3-0.4)$ & 4 \\
Ketamine+Midazolam+Acepromazine & $(5.0-7.0)+0.3+(0.02-0.04)$ & 2 & 2 \\
\hline Withoutpremedication & - & 4 & 1 \\
\hline Total & - & $\mathbf{2 0 0}$ & 2 \\
\hline
\end{tabular}

Source: Elaboration of the authors.

Table 3. Details of induction regimens with numbers of dogs respective frequency (\%), which received each regimen.

\begin{tabular}{|c|c|c|c|}
\hline Drug or association & $\begin{array}{c}\text { Dose }\left(\mathrm{mg} / \mathrm{kg}^{-1}\right) \\
\text { (minimum- maximum) }\end{array}$ & Cases (n) & Frequency $(\%)$ \\
\hline Propofol & $(3.0-5.0)$ & 99 & 49.5 \\
\hline Propofol & $(8.0-10.0)$ & 2 & 1 \\
\hline Propofol + Fentanyl* & $(3.0-5.0)+(2.0-5.0)$ & 43 & 21.5 \\
\hline Propofol + Ketamine & $3.0+(0.5-1.0)$ & 29 & 14.5 \\
\hline Propofol + Midazolam & $(3.0-5.0)+(0.2-0.3)$ & 20 & 10 \\
\hline Propofol + Diazepam & $(3.0-5.0)+0.5$ & 2 & 1 \\
\hline $\begin{array}{c}\text { Propofol + Lidocaine }+ \\
\text { Ketamine }\end{array}$ & $(2.0-3.0)+1.0+1.0$ & 5 & 2.5 \\
\hline Total & - & 200 & 100 \\
\hline
\end{tabular}

* Fentanyl doses showed in $\mu \mathrm{g} / \mathrm{kg}^{-1}$.

Source: Elaboration of the authors.

Mean duration of CRI was $136.2 \pm 42.9 \mathrm{~min}$ (Table 4). Fentanyl, alone or combined with other agents, was the main drug used in the infusion protocols. Among the $25(100 \%)$ CRI protocols reported, fentanyl-lidocaine-ketamine was used in $65(32.5 \%)$ dogs, followed by fentanyl (25\%), fentanyl-lidocaine (13\%), and fentanyl-ketamine $(7.5 \%)$. Excessive variation in the numbers of dogs treated according to infusion $\operatorname{drug}(\mathrm{s})$ and dose(s) precluded comparison of the occurrence of anesthetic complications among protocols.
Anesthetic complications are shown in Table 5, with the respective numbers for each protocol. The anesthetic complications were registered during CRI and 128 episodes were observed. The most common complications were hypotension, hypertension, and tachycardia, which occurred in $43(21,5 \%), 35$ $(17,5 \%)$, and $19(9,5 \%)$, respectively. The frequency of incidence of complications and the correlation with CRI are shown in Table 5, Figure 1. 
Table 4. Details of CRI regimens with respective doses, number of dogs treated with each CRI, frequency (\%) and CRI duration.

\begin{tabular}{|c|c|c|c|c|}
\hline Drug or association & $\begin{array}{c}\text { Dose } \\
\left(\mu \mathrm{g} / \mathrm{kg} / \mathrm{min}^{-1}\right)\end{array}$ & $\begin{array}{c}\text { Cases } \\
\text { (n) }\end{array}$ & $\begin{array}{c}\text { Frequency } \\
(\%)\end{array}$ & $\begin{array}{c}\text { Duration of } \\
\text { CRI (h) }\end{array}$ \\
\hline Fentanyl & 0.083 & 47 & 23.5 & 2.14 \\
\hline Fentanyl & 0.125 & 2 & 1 & 1.13 \\
\hline Fentanyl & 0.166 & 1 & 0.5 & 2.25 \\
\hline Fentanyl + Lidocaine & $0.083+30$ & 21 & 10.5 & 2.01 \\
\hline Fentanyl + Lidocaine & $0.041+50$ & 1 & 0.5 & 2.0 \\
\hline Fentanyl + Lidocaine & $0.125+30$ & 2 & 1 & 2.5 \\
\hline Fentanyl + Lidocaine & $0.166+30$ & 1 & 0.5 & 2.0 \\
\hline Fentanyl + Lidocaine & $0.25+30$ & 1 & 0.5 & 2.0 \\
\hline Fentanyl + Ketamine & $0.083+15$ & 15 & 7.5 & 2.23 \\
\hline Fentanyl + Lidocaine + Ketamine & $0.083+50+10$ & 1 & 0.5 & 3.75 \\
\hline Fentanyl + Lidocaine + Ketamine & $0.083+30+15$ & 49 & 24.5 & 2.33 \\
\hline Fentanyl + Lidocaine + Ketamine & $0.083+50+15$ & 1 & 0.5 & 2.0 \\
\hline Fentanyl + Lidocaine + Ketamine & $0.083+50+20$ & 1 & 0.5 & 3.5 \\
\hline Fentanyl + Lidocaine + Ketamine & $0.125+30+15$ & 6 & 3 & 2.46 \\
\hline Fentanyl + Lidocaine + Ketamine & $0.166+30+15$ & 7 & 3.5 & 2.32 \\
\hline Lidocaine + Ketamine & $30+15$ & 9 & 4.5 & 2.75 \\
\hline Lidocaine + Ketamine & $50+10$ & 3 & 1.5 & 2.67 \\
\hline Morphine & 1.66 & 1 & 0.5 & 1.5 \\
\hline Morphine + Lidocaine & $1.66+30$ & 6 & 3.0 & 2 \\
\hline Morphine + Ketamine & $1.66+15$ & 1 & 0.5 & 4 \\
\hline Morphine + Lidocaine + Ketamine & $1.66+30+15$ & 8 & 4.0 & 1.46 \\
\hline Morphine + Lidocaine + Ketamine & $1.66+50+10$ & 1 & 0.5 & 2.5 \\
\hline Lidocaine & 30 & 5 & 2.5 & 2.55 \\
\hline Lidocaine & 50 & 1 & 0.5 & 1 \\
\hline Ketamine & 15 & 9 & 4.5 & 1.69 \\
\hline Total & - & 200 & 100 & - \\
\hline
\end{tabular}

Source: Elaboration of the authors. 
Table 5. Incidence of anesthetic complication in each different CRI [number of dogs (frequency considering of total dogs treated with respective CRI)] in 200 records evaluated.

\begin{tabular}{|c|c|c|}
\hline $\begin{array}{c}\text { Anesthetic } \\
\text { Complication }\end{array}$ & $\begin{array}{l}\text { Drug or association } \\
\text { [number of anesthetic complications related to each CRI (\%)] }\end{array}$ & $\begin{array}{l}\text { Frequency* } \\
\quad(\%)\end{array}$ \\
\hline Hypotension & $\begin{array}{c}\mathrm{F}^{1}[13(27,7 \%)] ; \mathrm{F}^{2}[2(100 \%)] ; \mathrm{F}^{3}[1(100 \%)] ; \mathrm{FL}^{1}[4(19 \%)] ; \mathrm{FL}^{4} \\
{[1(100 \%)] ; \mathrm{FK}[2(13.3 \%)] ; \mathrm{FLK}^{2}[10(20.4 \%)] ; \mathrm{FLK}^{3}[1(100 \%)] ; \mathrm{FLK}^{4}} \\
{[1(16.7 \%)] ; \mathrm{FLK}^{5}[3(42.9 \%)] ; \operatorname{ML}[1(16.7 \%)] ; \mathrm{MLK}^{1}[1(12.5 \%)] ; \mathrm{L}} \\
{[1(20 \%)] ; \mathrm{K}[2(22.2 \%)]}\end{array}$ & 21.5 \\
\hline Hypertension & $\begin{array}{c}\mathrm{F}^{1}[9(19.1 \%)] ; \mathrm{FL}^{1}[5(23.8 \%)] ; \mathrm{FL}^{2}[1(100 \%)] ; \mathrm{FL}^{3}[1(50 \%)] ; \mathrm{FL}^{4} \\
{[1(100 \%)] ; \mathrm{FK}[3(20 \%)] ; \mathrm{FLK}^{1}[1(100 \%)] ; \mathrm{FLK}^{2}[7(14.3 \%)] ; \mathrm{FLK}^{4}} \\
{[2(33.3 \%)] ; \mathrm{FLK}^{5}[2(28.6 \%)] ; \mathrm{LK}[1(11.1 \%)] ; \mathrm{MLK}^{1}[1(12.5 \%)] ; \mathrm{L}} \\
{[1(20 \%)]}\end{array}$ & 17.5 \\
\hline Tachycardia & $\begin{array}{c}\mathrm{F}^{1}[3(6.4 \%)] ; \mathrm{FK}[4(26.7 \%)] ; \mathrm{FLK}^{2}[4(8.2 \%)] ; \mathrm{FLK}^{4}[2(33.3 \%)] ; \mathrm{FLK}^{5} \\
{[1(14.3 \%)] ; \operatorname{ML}[1(16.7 \%)] ; \operatorname{MLK}^{1}[1(12.5 \%)] ; \mathrm{L}[1(20 \%)] ; \mathrm{K}[2(22.2 \%)]}\end{array}$ & 9.5 \\
\hline Bradycardia & $\begin{array}{c}\left.\mathrm{F}^{1}[4(8.5 \%)] ; \mathrm{FL}^{1}[1(4.8 \%)] ; \mathrm{FL}^{2}[1(100 \%)] ; \mathrm{FK}^{2}(13.3 \%)\right] ; \mathrm{FLK}^{2} \\
{[3(6.1 \%)] ; \mathrm{FLK}^{3}[1(100 \%)] ; \mathrm{FLK}^{4}[1(16.7 \%)] ; \mathrm{FLK}^{5}[3(42.9 \%)] ; \mathrm{MLK}^{1}} \\
{[1(12.5 \%)]}\end{array}$ & 8.5 \\
\hline Tachypnea & $\mathrm{F}^{1}[2(4.25 \%)] ; \mathrm{FLK}^{4}[1(16.7 \%)] ; \operatorname{LK}[1(11.1 \%)] ; \operatorname{MLK}^{2}[1(100 \%)]$ & 2.5 \\
\hline Apnea & $\begin{array}{c}\mathrm{F}^{1}[2(4.25 \%)] ; \mathrm{F}^{3}[1(100 \%)] ; \mathrm{FL}^{2}[1(100 \%)] ; \mathrm{FL}^{4}[1(100 \%)] ; \mathrm{FLK}^{4} \\
{[2(33.3 \%)] ; \mathrm{FLK}^{5}[1(14.3 \%)] ; \mathrm{LK}[1(11.1 \%)]}\end{array}$ & 4.5 \\
\hline $\begin{array}{l}\text { Atrioventricular } \\
\text { Block }\end{array}$ & $\mathrm{FL}^{1}[1(4.8 \%)] ; \mathrm{FL}^{4}[1(100 \%)]$ & 1.0 \\
\hline $\begin{array}{l}\text { Ventricular } \\
\text { Tachycardia }\end{array}$ & $\operatorname{FLK}^{2}[1(2 \%)]$ & 0.5 \\
\hline Branch block & $\operatorname{FLK}^{4}[1(16.7 \%)]$ & 0.5 \\
\hline Seizure & $\operatorname{MLK}^{1}[1(12.5 \%)]$ & 0.5 \\
\hline
\end{tabular}

Doses in $\mu \mathrm{g} / \mathrm{kg}^{-1} / \mathrm{min}^{-1}$; Fentanyl (0.083) $-\mathbf{F}^{\mathbf{1}}$; Fentanyl (0.125)- $\mathbf{F}^{2}$; Fentanyl (0.166) $-\mathbf{F}^{3}$; Fentanyl (0.083) + Lidocaine (30)- $\mathbf{F L}^{\mathbf{1}}$; Fentanyl (0.125) + Lidocaine (30) $-\mathbf{F L}^{2}$; Fentanyl (0.166) + Lidocaine (30) $-\mathbf{F L}^{3}$; Fentanyl (0.25) + Lidocaine (30)- $\mathbf{F L}^{4}$; Fentanyl (0.083) + Ketamine (15)- FK; Fentanyl (0.083) + Lidocaine (50) + Ketamine (10)- FLK ${ }^{1}$; Fentanyl (0.083) + Lidocaine (30) + Ketamine (15)- FLK' Fentanyl (0.083) + Lidocaine (50) + Ketamine (15)- FLK'; Fentanyl (0.125) + Lidocaine (30) + Ketamine (15)- FLK $^{4}$; Fentanyl (0.166) + Lidocaine (30) + Ketamine (15)-FLK ${ }^{5}$; Lidocaine (30) + Ketamine (15)-LK; Morphine (1.66) + Lidocaine (30)- ML; Morphine (1.66) + Lidocaine (30) + Ketamine (15)- MLK' ; Morphine (1.66) + Lidocaine (50) + Ketamine (10)- MLK ${ }^{2}$; Lidocaine (30)- L; Ketamine(15)-K. * Total frequency considering total records evaluated.

Source: Elaboration of the authors.

From the records, hypotension was treated by reducing administration of isoflurane and giving a bolus of fluids (lactated Ringer's) over 10 minutes. In the other hypotensive dogs, the following drugs were used: 7 of the $43(16.27 \%)$ were treated with phenylephrine, $4(9.3 \%)$ with dobutamine, and 2 with ephedrine $(4.65 \%)$. No interruption was carried out in CRI during anesthesia even in the face of complications.
Cardiovascular response to surgical stimulation was observed in 54 (27\%) records. This complication occurred in different protocols, such as fentanyl, fentanyl-lidocaine, and fentanyl-lidocaineketamine. 
Figure 1. Frequency of the each anesthetic complication considering a total of 128 (100\%) episodes in 200 dogs treated with different CRI.

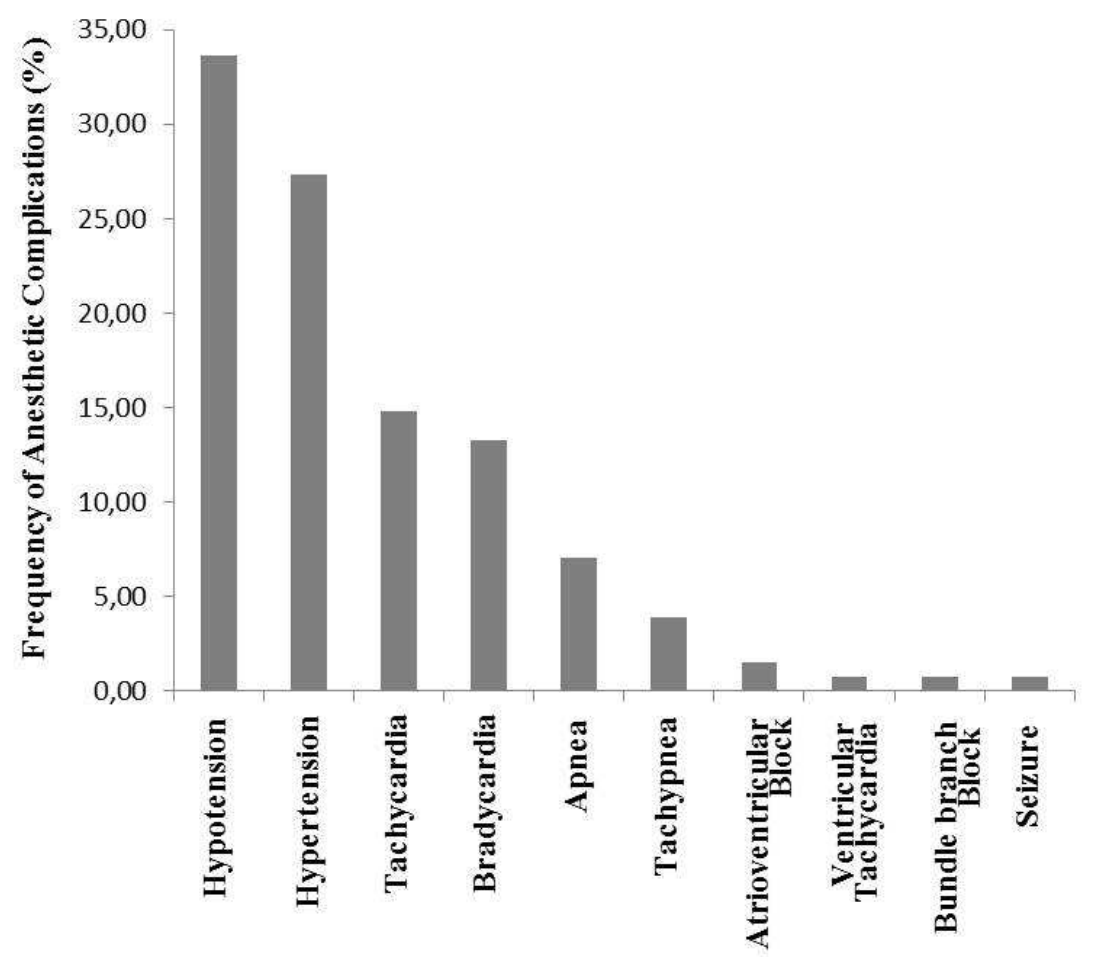

Source: Elaboration of the authors.

Cardiac arrhythmia was reported in only 4 dogs. Ventricular tachycardia and bundle branch block were observed in the 2 dogs that received fentanyllidocaine-ketamine CRI, and atrioventricular block was observed in the 2 dogs that received fentanyllidocaine CRI (Table 5). Apnea were observed in 9 records with CRIs protocols with fentanyl and signs of respiratory depression, such as hypercapnia, were present in dogs treated with morphine $(1.66 \mu \mathrm{g}$ $\left.\mathrm{kg}^{-1} \mathrm{~min}^{-1}\right)$ and ketamine $\left(15 \mu \mathrm{g} \mathrm{kg}^{-1} \mathrm{~min}^{-1}\right)$; fentanyl $\left(0.083 \mu \mathrm{g} \mathrm{kg}^{-1} \mathrm{~min}^{-1}\right)$; fentanyl $\left(0.083 \mu \mathrm{g} \mathrm{kg}^{-1} \mathrm{~min}^{-1}\right)$ and ketamine $\left(15 \mu \mathrm{g} \mathrm{kg}^{-1} \mathrm{~min}^{-1}\right)$; fentanyl $(0.083 \mu \mathrm{g}$ $\left.\mathrm{kg}^{-1} \mathrm{~min}^{-1}\right)$, lidocaine $\left(30 \mu \mathrm{g} \mathrm{kg}^{-1} \mathrm{~min}^{-1}\right)$, and ketamine $\left(15 \mu \mathrm{g} \mathrm{kg} \mathrm{min}^{-1}\right)$; fentanyl $\left(0.125 \mu \mathrm{g} \mathrm{kg}^{-1} \mathrm{~min}^{-1}\right)$, lidocaine $\left(30 \mu \mathrm{g} \mathrm{kg}^{-1} \mathrm{~min}^{-1}\right)$, and ketamine $\left(15 \mu \mathrm{g} \mathrm{kg}^{-1}\right.$ $\left.\mathrm{min}^{-1}\right)$; and fentanyl $\left(0.125 \mu \mathrm{g} \mathrm{kg}^{-1} \mathrm{~min}^{-1}\right)$ and lidocaine $\left(30 \mu \mathrm{g} \mathrm{kg} \mathrm{min}^{-1}\right)$. There was an increase in the expired fraction of $\mathrm{CO}_{2}(>50 \mathrm{mmHg})$ necessitating controlled ventilation. Of all the records evaluated, only $15 \mathrm{dogs}$ required controlled ventilation. The criteria for installation of controlled ventilation were respiratory depression, difficulty stabilization of the anesthetic plane, or both. We did not observe anesthetic complications associated with infusion of fentanyl $\left(0.041 \mu \mathrm{g} \mathrm{kg}^{-1} \mathrm{~min}^{-1}\right)$ and lidocaine $(50 \mu \mathrm{g}$ $\left.\mathrm{kg}^{-1} \mathrm{~min}^{-1}\right)$; fentanyl $\left(0,083 \mu \mathrm{g} \mathrm{kg}^{-1} \mathrm{~min}^{-1}\right)$, lidocaine $\left(50 \mu \mathrm{g} \mathrm{kg}^{-1} \mathrm{~min}^{-1}\right)$, and ketamine $\left(20 \mu \mathrm{g} \mathrm{kg}^{-1} \mathrm{~min}^{-1}\right)$; lidocaine $\left(50 \mu \mathrm{g} \mathrm{kg}^{-1} \mathrm{~min}^{-1}\right)$ and ketamine $(10 \mu \mathrm{g}$ $\left.\mathrm{kg}^{-1} \mathrm{~min}^{-1}\right)$; morphine $\left(1.66 \mu \mathrm{g} \mathrm{kg}^{-1} \mathrm{~min}^{-1}\right)$; morphine $\left(1,66 \mu \mathrm{g} \mathrm{kg}^{-1} \mathrm{~min}^{-1}\right)$ and ketamine $\left(15 \mu \mathrm{g} \mathrm{kg}^{-1} \mathrm{~min}^{-1}\right)$; and lidocaine $\left(50 \mu \mathrm{g} \mathrm{kg}^{-1} \mathrm{~min}^{-1}\right)$.

Epidural block was performed in 71 dogs (35.5\%), independent of CRI protocol. In these dogs, hypotension presented in only 17 [8(47.5\%) dogs with fentanyl-lidocaine-ketamine CRI, 5 (29.4\%) with fentanyl CRI, and 1 (5.8\%) each with lidocaine, ketamine, fentanyl-ketamine and fentanyl-lidocaine CRIs].

Significant reductions were observed in the 
consumption of isoflurane (vol \%) during the anesthetic period when compared with the first 30 minutes in the fentanyl and fentanyl-lidocaineketamine protocols. The isoflurane consumption was reduced by $15.7 \%-21.05 \%$ after 30 minutes of the CRI in the fentanyl $\left(0.083 \mu \mathrm{g} \mathrm{kg}^{-1} \mathrm{~min}^{-1}\right)$ protocol and the fentanyl $\left(0.083 \mu \mathrm{g} \mathrm{kg}^{-1} \mathrm{~min}^{-1}\right)$, lidocaine $\left(30 \mu \mathrm{g} \mathrm{kg}^{-1} \mathrm{~min}^{-1}\right)$, and ketamine $(15 \mu \mathrm{g}$ $\left.\mathrm{kg}^{-1} \mathrm{~min}^{-1}\right)$ protocol $(\mathrm{p}<0.05)$. In the other protocols, no significant differences were found during the anesthetic period compared with the first 30 minutes $(\mathrm{p}>0.05)$ (Table 6).

Mortality was not observed in any record.

Table 6. Mean of isoflurane consumption (V\%) in dogs receiving different CRI ( $\mathrm{n}=$ number of dogs) with respective doses, evaluated in 120 minutes.

\begin{tabular}{|c|c|c|c|c|c|}
\hline \multirow{2}{*}{ Drug or association } & \multicolumn{5}{|c|}{$\begin{array}{c}\text { Isoflurane consumption } \\
\text { (Vaporization in volume percent }-\mathrm{V} \%)\end{array}$} \\
\hline & $\begin{array}{c}\text { Dose } \\
\left(\mu \mathrm{g} / \mathrm{kg} / \mathrm{min}^{-1}\right)\end{array}$ & 0-30min & $31-60 \mathrm{~min}$ & $61-90 \mathrm{~min}$ & 91-120min \\
\hline $\begin{array}{c}\text { Fentanyl } \\
(\mathrm{n}=39)\end{array}$ & 0.083 & $1.9 \pm 0.6$ & $1.5 \pm 0.6^{*}$ & $1.6 \pm 0.5^{*}$ & $1.5 \pm 0.5^{*}$ \\
\hline $\begin{array}{l}\text { Fentanyl }+ \text { Lidocaine } \\
\qquad(\mathrm{n}=15)\end{array}$ & $0.083+30$ & $2.3 \pm 0.7$ & $2.3 \pm 0.9$ & $2.1 \pm 0.9$ & $1.8 \pm 0.5$ \\
\hline $\begin{array}{c}\text { Fentanyl }+ \text { Ketamine } \\
(\mathrm{n}=14)\end{array}$ & $0.083+15$ & $1.8 \pm 0.6$ & $1.7 \pm 0.7$ & $1.6 \pm 0.7$ & $1.8 \pm 0.5$ \\
\hline $\begin{array}{l}\text { Fentanyl }+ \text { Lidocaine }+ \text { Ketamine } \\
(\mathrm{n}=42)\end{array}$ & $0.083+30+15$ & $1.9 \pm 0.5$ & $1.6 \pm 0.6^{*}$ & $1.5 \pm 0.6^{*}$ & $1.5 \pm 0.4 *$ \\
\hline $\begin{array}{l}\text { Fentanyl }+ \text { Lidocaine }+ \text { Ketamine } \\
\qquad(\mathrm{n}=7)\end{array}$ & $0.166+30+15$ & $2.7 \pm 1.1$ & $2.1 \pm 1.6$ & $2.3 \pm 1.1$ & $2.1 \pm 0.9$ \\
\hline $\begin{array}{c}\text { Lidocaine }+ \text { Ketamine } \\
(\mathrm{n}=9)\end{array}$ & $30+15$ & $1.6 \pm 0.3$ & $1.6 \pm 0.3$ & $1.5 \pm 0.4$ & $1.4 \pm 0.5$ \\
\hline $\begin{array}{c}\text { Morphine+ Lidocaine } \\
(\mathrm{n}=7)\end{array}$ & $1.66+30$ & $1.8 \pm 0.4$ & $1.6 \pm 0.5$ & $1.6 \pm 0.5$ & $1.6 \pm 0.5$ \\
\hline $\begin{array}{l}\text { Morphine }+ \text { Lidocaine }+ \text { Ketamine } \\
(\mathrm{n}=7)\end{array}$ & $1.66+30+15$ & $1.6 \pm 0.5$ & $1.5 \pm 0.4$ & $1.4 \pm 0.5$ & $1.1 \pm 0.4$ \\
\hline $\begin{array}{c}\text { Ketamine } \\
(\mathrm{n}=8)\end{array}$ & 15 & $1.6 \pm 0.4$ & $1.6 \pm 0.6$ & $1.5 \pm 0.8$ & $1.9 \pm 0.8$ \\
\hline
\end{tabular}

* Significantly $(\mathrm{p}<0.05)$ different from baseline $(0-30 \mathrm{~min})$ data within each time.

Source: Elaboration of the authors. 
Table 7. A list of the procedures performed, relative numbers and frequencies of cases in 200 dogs.

\begin{tabular}{|c|c|c|}
\hline Surgical Procedures & $\begin{array}{c}\text { Cases } \\
(n)\end{array}$ & $\begin{array}{l}\text { Frequency } \\
(\%)\end{array}$ \\
\hline Total unilateral mastectomy + ovariohisterectomy $(\mathrm{OH})$ & 45 & 22.5 \\
\hline Total unilateral mastectomy & 33 & 16.5 \\
\hline Nodulectomy & 24 & 12 \\
\hline Therapeutic OH (pyometra) & 5 & 2.5 \\
\hline Elective $\mathrm{OH}$ & 3 & 1.5 \\
\hline Toracotomy & 1 & 0.5 \\
\hline Tracheal suture & 1 & 0.5 \\
\hline Forelimb amputation & 5 & 2.5 \\
\hline Orthopedic surgey forelimb & 11 & 5.5 \\
\hline Orthopedic surgery hindlimb & 14 & 7 \\
\hline Spine surgery (laminectomy. ventral slot. stabilization. fenestration) & 29 & 14.5 \\
\hline Ophthalmic surgery (enucleation. covering 360) & 2 & 1 \\
\hline Perineal surgery (perineal hernia. episiotomy. vaginal prolapse reduction) & 5 & 2.5 \\
\hline Dental surgery (mandibulectomy. osteosynthesis jaw. tooth extraction) & 4 & 2 \\
\hline $\begin{array}{c}\text { Laparotomy (gastrotomy. enterotomy. splenectomy. cystotomy. nephrectomy. ectopic } \\
\text { testis. prostate omentalization) }\end{array}$ & 16 & 8 \\
\hline Nodulectomy + Exploratory laparotomy & 1 & 0.5 \\
\hline Nodulectomy + Hepatic lobectomy & 1 & 0.5 \\
\hline Total & 200 & 100 \\
\hline
\end{tabular}

Source: Elaboration of the authors.

\section{Discussion}

Combined use of drugs in anesthesia facilitates pain control and reduces or prevents adverse events in balanced analgesia. In this retrospective study, the CRI protocols provided effective intraoperative stability with few significant adverse effects and reduction in anesthetic requirement depending on the drug combination. The doses and drugs evaluated in the records are already indicated for use in CRI and were in accordance with low doses described in the literature. These protocols are known to reduce the isoflurane requirement without adversely affecting hemodynamics or obvious adverse effects (LUCAS et al., 2001; MUIR; WIESE; MARCH, 2003).

In this study, we included records of various surgical procedures and CRI infusion protocols with the aim to investigate different clinical conditions. We chose to present the findings in a descriptive way because of the difficulty of attributing a complication to a specific infusion protocol. We aimed to reveal the possible complications that can occur in dogs subjected to different techniques of CRI in the clinical setting.

The role of a CRI protocol in the occurrence of an anesthetic complication was unclear; this can be explained in part by the low number of repetitions with some protocols, which did not allow a comparative analysis. Nevertheless, we considered possible causes and associations of CRI protocols regarding such complications, even in the case of isolated complications.

Despite no adverse effects being observed with use of the different anesthetic premedication and induction agents in this retrospective study, we cannot exclude the possibility that these agents might have affected the results. Anesthetic 
complications such as hypotension and cardiac arrhythmias might have been delayed effects of the anesthetic premedication or isoflurane anesthesia.

The presence of tachycardia and hypertension during anesthesia did not differ among the protocols evaluated in this study and was likely attributable to sympathetic stimulation by surgical manipulation. Previous authors reported reduction in heart rate with use of morphine (LUCAS et al., 2001; MUIR; WIESE; MARCH, 2003) and fentanyl (STEAGALL et al., 2006; BUFALARI et al., 2007; UEYAMA et al., 2009) CRIs. Steagall et al. (2006) showed that hypertension spikes were avoided by fentanyl CRI administration in dogs, compared with a control group.

Hypotensive episodes were readily responsive to reducing the amount of anesthetic delivered or to administration of a fluid bolus or sympathomimetic drugs. However, the improvement of arterial blood pressure after these measures might have been caused by the concomitant reduction of anesthetic agent with the CRI. Several agents used in CRI can trigger hypotension, such as fentanyl and morphine (LAMONT; MATHEWS, 2007). However, previous studies observed that fentanyl CRI causes an increase in arterial blood pressure, possibly due to the significant reduction in inhalant requirements, or no change in this parameter, probably because fentanyl-induced bradycardia negates the expected improvement in blood pressure (STEAGALL et al., 2006; UEYAMA et al., 2009). Another study showed that, although morphine CRI induced relatively high histamine release even at low doses, this is not associated with adverse physiological effects such as hypotension in healthy dogs (GUEDES; RUDÉ; RIDER, 2006). Therefore, in our retrospective study, considering that hypotension was not observed in most of the CRI protocols evaluated, it is presumed that such a complication in this study could have been due to the effects of isoflurane anesthesia or the anesthetic premedication.
Compared with the other drugs, lidocaine CRI causes an increase in arterial blood pressure when administered athigh doses, probably due to decreased inhaled anesthetic concentration (VALVERDE et al., 2004; MATSUBARA et al., 2009), or does not cause any change in blood pressure (ORTEGA; CRUZ, 2011). The effects of a ketamine CRI on blood pressure are controversial. Previous study showed a significant increase in this parameter in healthy dogs after an infusion dose that yielded a plasma concentration of $2 \mu \mathrm{g} \mathrm{ml}^{-1}$ (BOSCAN et al., 2005), and another study showed that ketamine CRI did not increase the blood pressure. However, the latter experiment was developed in hypovolemic dogs (DUQUE et al., 2005).

Respiratory depression observed in some dogs was successfully treated with assisted or controlled ventilation. Regardless of CRI protocol, the dogs evaluated in the study were capable of modulating their own respiratory rate after discontinuing mechanical ventilation. Despite the fact that the drugs used in the CRI protocols, such as fentanyl (BUFALARI et al., 2007) and morphine (LAMONT; MATHEWS, 2007), are capable of triggering respiratory depression even at low doses, several variables prevented us from affirming that the respiratory depression was associated with CRI, such as breed, body condition, recumbency and surgical procedure.

The seizure observed in one dog treated with morphine-lidocaine-ketamine CRI was assigned to residual contrast agent employed in myelography immediately before the surgical procedure. The seizure episode occurred during tracheal extubation. Lidocaine can potentially cause nervous system toxicity, but the dose used in the CRI was significantly lower than that associated with the onset of seizures (WILCKE; DAVIS; NEFF-DAVIS, 1983). Seizure suppression during general anesthesia has been ascribed to the ability of inhalant anesthetics to protect against the central nervous system toxicity of lidocaine (PYPENDOP; ILKIW, 2005). 
The individual contribution of CRI, isoflurane, or regional block to cardiovascular changes remains undefined. Although the contributory effect of the epidural block on the observed hypotension could not be isolated, we should consider that the combination of CRI and epidural block may trigger hypotension, even though epidural anesthesia alone potentiates hypotension (IFF; MOENS, 2008).

A limitation of this study was the difficulty in determining the antinociceptive effects of the drugs used in CRI. This limitation was due to different surgical stimuli and use of additional regional block techniques. However, these drugs increase the nociceptive threshold thereby decreasing the general anesthetic requirement. Significant differences were observed mainly in CRI protocols with fentanyl or fentanyl-lidocaine-ketamine (FLK). Similar results were reported in previous studies that evaluated the reduction of isoflurane MAC after the administration of combination CRI. Muir, Wiese and March (2003) concluded that morphine-lidocaine-ketamine (MLK), when administered by CRI, reduced the isoflurane MAC by $45 \%$. Further, Aguado, Benito and Segura (2011) observed a similar reduction in isoflurane MAC after MLK CRI and observed a 97\% reduction after FLK CRI.

We believe that the absence of statistical differences in the other protocols is directly related to the number of repetitions, because several studies have shown significant MAC reductions with the protocols adopted in this retrospective study. One study showed that ketamine CRI, when administered in doses that achieved plasma concentrations of 0.5 , $1,2,5,8$, and $11 \mu \mathrm{g} \mathrm{ml}^{-1}$, reduced isoflurane MAC in dogs by $10.89 \%$ to $39.48 \%, 26.77 \%$ to $43.74 \%$, $25.24 \%$ to $84.89 \%, 44.34 \%$ to $78.16 \%, 69.62 \%$ to $92.31 \%$, and $71.97 \%$ to $95.42 \%$, respectively (SOLANO et al, 2006). Furthermore, use of lidocaine has produced an MAC reduction of $18.7 \%$ with $50 \mu \mathrm{g} \mathrm{kg}^{-1} \mathrm{~min}^{-1}$ and $43.3 \%$ with $200 \mu \mathrm{g} \mathrm{kg}^{-1}$ $\min ^{-1}$ (VALVERDE et al., 2004).
In conclusion, CRI represents a valid component of balanced anesthesia in dogs, appears safe, and has a low incidence of adverse effects. However, continuous monitoring of hemodynamic parameters to rapidly detect anesthetic complications is required. We believe that future studies aimed at investigating the use of CRI and a clinical description in a greater number of patients may allow better characterization and refinement of this technique.

\section{References}

AGUADO, D.; BENITO, J.; SEGURA, I. A. G. Reduction of the minimum alveolar concentration of isoflurane in dogs using a constant rate of infusion of lidocaine-ketamine in combination with either morphine or fentanyl. The Veterinary Journal, London, v. 189, n. 1, p. 63-66, 2011.

ANDERSON, M. K.; DAY, T. K. Effects of morphine and fentanyl constant rate infusion on urine output in healthy and traumatized dogs. Veterinary Anaesthesia and Analgesia, Oxford, v. 35, n. 6, p. 528-536, 2008.

BERGADANO, A.; ANDERSEN, O. K.; ARENDTNIELSEN, L.; THEURILLAT, R.; THORMANN, W.; SPADAVECCHIA, C. Plasma levels of a low-dose constant-rate-infusion of ketamine and its effect on single and repeated nociceptive stimuli in conscious dogs. The Veterinary Journal, London, v. 182, n. 2, p. 252-260, 2009.

BOSCAN, P.; PYPENDOP, B. H.; SOLANO, A. M.; ILKIW, J. E. Cardiovascular and respiratory effects of ketamine infusions in isoflurane-anesthetized dogs before and during noxious stimulation. American Journal of Veterinary Research, Chicago, v. 66, n. 12, p. 2122-2129, 2005.

BUFALARI, A.; DI MEO, A.; NANNARONE, S.; PADUA, S.; ADAMI, C. Fentanyl or sufetanil continuous infusion during isoflurane anaesthesia in dogs: Clinical experiences. Veterinary Research Communications, Philadelphia, v. 31, n. 1, p. 277-280, 2007.

CORLETTO, F. Multimodal and balanced analgesia. Veterinary Research Communications, Philadelphia, v. 31, n. 1, p. 59-63, 2007.

DUQUE, J. C.; SOUZA, A. P.; NUNES, N.; HONSHO, C. S.; TALIERI, I. Continuous infusion of ketamine in hypovolemic dogs anesthetized with desflurane. Journal of Veterinary Emergency and Critical Care, San Antonio, v. 15, n. 2 , p. $92-99,2005$. 
GUEDES, A. G. P.; PAPICH, M. G.; RUDÉ, E. P.; RIDER, M. A. Pharmacokinetics and physiological effects of two intravenous infusion rates of morphine in conscious dogs. Journal of Veterinary Pharmacology and Therapeutics, Oxford, v. 30, n. 3, p. 224-233, 2007.

GUEDES, A. G. P.; RUDÉ, E. P.; RIDER, M. A. Evaluation of histamine release during constant rate infusion of morphine in dogs. Veterinary Anaesthesia and Analgesia, Oxford, v. 33, n. 1, p. 28-35, 2006.

IFF, I.; MOENS, Y. Two cases of bradyarrhythmia and hypotension after extradural injections in dogs. Veterinary Anaesthesia and Analgesia, Oxford, v. 35, n. 3, p. 265-269, 2008.

JONES, R. S. Combining local and general anaesthesia for better pain relief in dogs and cats. The Veterinary Journal, London, v. 178, n. 2, p. 161-162, 2008.

KEHLET, H.; DAHL, J. B. Anaesthesia, surgery, and challenges in postoperative recovery. The Lancet, London, v. 362, n. 9399, p. 1921-1928, 2003.

KUKANICH, B.; LASCELLES, B. D.; PAPICH, M. G. Use of a von Frey device for evaluation of pharmacokinetics and pharmacodynamics of morphine after intravenous administration as an infusion or multiple doses in dogs. American Journal of Veterinary Research, Chicago, v. 66, n. 11, p. 1968-1974, 2005.

LAMONT, L. A. Adjunctive analgesic therapy in veterinary medicine. Veterinary Clinics of North America: Small Animal Practice, Philadelphia, v. 38, n. 6, p. 1187-1203, 2008.

LAMONT, L. A.; MATHEWS, K. A. Opioids, Nonsteroidal anti-inflammatories, and analgesic adjuvants. In: TRANQUILI, W. J.; THURMON, J. C.; GRIMM, K. A. Lumb \& Jones' Veterinary anesthesia and analgesia. $4^{\text {th }} \mathrm{ed}$. Ames: Blackwell Publishing; 2007. p. 241-272.

LUCAS, A. N.; FIRTH, A. M.; ANDERSON, G. A.; VINE, J. H.; EDWARDS, G. A. Comparison of the effects of morphine administered by constant-rate intravenous infusion or intermittent intramuscular injection in dogs. Journal of the American Veterinary Medical Association, New York, v. 218, n. 6, p. 884-891, 2001.

MATSUBARA, L. M.; OLIVA, V. N.; GABAS, D. T.; OLIVEIRA, G. C.; CASSETARI, M. L. Effect of lidocaine on the minimum alveolar concentration of sevoflurane in dogs. Veterinary Anaesthesia and Analgesia, Oxford, v. 36, n. 5, p. 407-413, 2009.
MUIR, W. W.; WIESE, A. J.; MARCH, P. A. Effects of morphine, lidocaine, ketamine, and morphine-lidocaineketamine drug combination on minimum alveolar concentration in dogs anesthetized with isoflurane. American Journal of Veterinary Research, Chicago, v. 64, n. 9, p. 1155-1160, 2003.

ORTEGA, M.; CRUZ, I. Evaluation of a constant rate infusion of lidocaine for balanced anesthesia in dogs undergoing surgery. Canadian Veterinary Journal, Guelph, v. 52, n. 8, p. 856-860, 2011.

PYPENDOP, B. H.; ILKIW, J. E. The effects of intravenous lidocaine administration on the minimum alveolar concentration of isoflurane in cats. Anesthesia and Analgesia, Cleveland, v. 100, n. 1, p. 97-101, 2005.

SMITH, L. J.; BENTLEY, E.; SHIH, A.; MILLER, P. E. Systemic lidocaine infusion as an analgesic for intraocular surgery in dogs - a pilot study. Veterinary Anaesthesia Analgesia, Oxford, v. 31, n. 1, p. 53-63, 2004.

SOLANO, A. M.; PYPENDOP, B. H.; BOSCAN, P. L.; ILKIW, J. E. Effect of intravenous administration of ketamine on the minimum alveolar concentration of isoflurane in anesthetized dogs. American Journal of Veterinary Research, Chicago, v. 67, n. 1, p. 21-25, 2006.

STEAGALL, P. V. M.; NETO, F. J. T.; MINTO, B. W.; CAMPAGNOL, D.; CORREAA, M. A. Evaluation of the isoflurane-sparing effects of lidocaine and fentanyl during surgery in dogs. Journal of American Veterinary Medical Association, New York, v. 229, n. 4, p. 522-527, 2006.

THRALL, M. A.; BAKER, D. C.; CAMPBELL, T. W.; DENICOLA, D. B.; FETTMAN, M. J.; LASSEN, E. D.; REBAR, A.; WEISER, G. Veterinary hematology and clinical chemistry. São Paulo: Roca, 2006.

UEYAMA, Y.; LERCHE, P.; EPPLER, M.; MUIR, W. W. Effects of intravenous administration of perzinfotel, fentanyl, and a combination of both drugs on the minimum alveolar concentration of isoflurane in dogs. American Journal of Veterinary Research, Chicago, v. 70, n. 12, p. 1459-1464, 2009.

VALVERDE, A.; DOHERTY, T. J.; HERNANDEZ, $\mathrm{J}$.; DAVIES, W. Effect of lidocaine on the minimum alveolar concentration of isoflurane in dogs. Veterinary Anaesthesia Analgesia, Oxford v. 31, n. 4, p. 264-271, 2004. 
WAGNER, A. E.; WALTON, J. A.; HELLYER, P. W.; GAYNOR, J. S.; MAMA, K. R. Use of a low doses of ketamine administered by constant rate infusion as an adjunct for postoperative analgesia in dogs. Journal of the American Veterinary Medical Association, New York, v. 221, n. 1, p. 72-75, 2002.

WILCKE, J. R.; DAVIS, L. E.; NEFF-DAVIS, C. A. Determination of lidocaine concentrations reducing therapeutic and toxic effects in dogs. Journal of Veterinary Pharmacology and Therapeutics, Oxford, v. 6, n. 2, p. 105-112, 1983.

WILSON, J.; DOHERTY, T. J.; EGGER, C. M.; FIDLER, A.; COX, S.; ROHRBACH, B. Effects of intravenous lidocaine, ketamine, and the combination on the minimum alveolar concentration of sevoflurane in dogs. Veterinary Anaesthesia Analgesia, Oxford, v. 35, n. 4, p. 289-296, 2008. 